\title{
Floods from tailings dam failures
}

\author{
Rico, M. ${ }^{1}$, Benito², G., Díez-Herrero, A. ${ }^{3}$ \\ ${ }^{1}$ CSIC - Instituto Pirenaico de Ecología, Zaragoza, Spain \\ ${ }^{2}$ CSIC - Centro de Ciencias Medioambientales, Madrid, Spain \\ ${ }^{3}$ Geological Hazards Unit, Spanish Geological Survey (IGME), Madrid, Spain
}

\begin{abstract}
This paper compiles the available information on historic tailings dam failures with the purpose to establish simple correlations between tailings ponds geometric parameters (e.g. dam height, tailings volume) and the hydraulic characteristics of floods resulting from released tailings. Following the collapse of a mining waste dam, only a part of tailings and polluted water stored at the dam is released, and this outflow volume is difficult to estimate prior the incident. In this study, tailings' volume stored at the time of failure was shown to have a good correlation $\left(r^{2}=0.86\right)$ with the tailings outflow volume, and the volume of spilled tailings was correlated with its run-out distance $\left(\mathrm{r}^{2}=\right.$ 0.57). An envelope curve was drawn encompassing the majority of data points indicating the potential maximum downstream distance affected by a tailings' spill. The application of the described regression equations for prediction purposes needs to be treated with caution and with support of on-site measurement and observations. However, they may provide a universal baseline approximation on tailing outflow characteristics (even if detailed dam information is unavailable), which is of a great importance for risk analysis purposes.
\end{abstract}

Key words: tailings pond, mine waste, dam failure, dam break, risk analysis 


\section{INTRODUCTION}

Dams are structural barriers built mainly for water management (for example irrigation, hydroelectric power and/or flood control) or the storage of industrial and mineral processing waste. Tailings dams are a particular type of dam built to store mill and waste tailings from mining activities. Currently, thousands of tailings dams worldwide contain billions of tonnes of waste material from mineral processing activity at mine sites. A number of particular characteristics make tailings dams more vulnerable to failure than water storage dams, namely: (1) embankments formed by locally derived fills (soil, coarse waste, overburden from mining operations and tailings); (2) multistage raising of the dam to cope with the increase in solid material stored and effluent (plus runoff from precipitation) released; (3) the lack of regulations on specific design criteria; (4) dam stability requiring a continuous monitoring and control during emplacement, construction and operation of the dam; and (5) the high cost of remediation works following the closure of mining activities.

Ever since the earliest dams were built, there have been dam failures. However, most studies of dam-break floods have focused on water-storage dams, with only a few exceptions $[1,2,3,4]$. Tailings dam failures result from a variety of causal mechanisms (e.g. flooding, piping, overtopping, liquefaction, or a combination of several) spilling out polluted water and tailings with a variety of textural and physical-chemical properties, which may impact over the downstream socio-economic activities and ecological systems. A good example of the high socio-economic cost associated with tailings dam disasters is the Los Frailes (Aznalcollar) accident, a large scale sulphide tailings pond spill that occurred in April 1998, with ca. $€ 152$ million in socio-economic losses [5,6,7]. About $€ 147$ million was spent to correct the negative environmental and agricultural impacts, including restoration of the area's natural resources (average impact of $5.7 \times 10^{6} € / \mathrm{km}^{2}$ ) and ca. $€ 5$ million was dedicated to mitigate socio-economic and socio-labour impacts in the affected municipalities. In addition, uncountable impacts affected the region's production structure which produced a drop in sales from milk producers, farmers and fish industries. 
To date, most numerical models for dam break analysis have been developed for waterstorage dams. The purpose of these models has been to predict the flood characteristics (flood hydrograph, peak discharge, flood wave propagation time, etc.), this depending upon dam type (for example, earth, rockfill, concrete gravity, concrete arch etc), break mechanisms and breach size. A great effort is still needed, however, to establish a reliable general methodology for coping with hazard prediction from tailings dam failures, which may serve to classify tailings ponds according to their potential downstream damages. In tailings dam accidents, flow numerical models need to account for high sediment concentration floods. Jeyapaland et al. [2] applied a Bingham plastic model (TFLOW computer program) both for the Aberfan case and the Gypsum Tailings Dam incident (case 12 in Table 1) showing laminar flow behaviour of the tailings flood. Apart from complex hydraulic calculations applied to specific case studies, more simple estimations can be performed based on generic empirical relationships. In these equations, key hydrological parameters associated with dam failures (e.g. outflow volume, peak discharge, mine waste run-out distance) can be estimated from pre-failure physical characteristics of the dam (dam height, reservoir volume, etc.), based on reported historic dam failures. This approach has been successfully applied to estimate peak discharge and flood volume resulting from water-retention dam failures $[8,9,10]$. With tailings dams, empirical relationships are very limited probably due to the scarcity of reliable historical data. Lucia et al. [11] proposed a method to estimate the potential mine waste run-out distance (at slopes $<4^{\circ}$ ), based on historical tailings dam failures and using the value of the residual strength of liquefied tailings. Although these are based on simple empirical equations, the model requires some detailed geotechnical data of the material contained in the tailings ponds as well as on the geometry of the downstream valley, which are not always available or provided by the mining companies.

The aim of this paper is to propose a set of simple empirical equations, to describe tailings pond characteristics and outflow hydraulic behaviour, based on data from historic dam failures. Although accuracy of these estimations should be approached with great caution, the equations provide a first and universal way for simple 
estimations on potential risk and impact related to tailings dam breaks, using basic physical dam information.

\section{METHODOLOGY}

Several investigations have attempted to summarise the causes of major tailings dam failures throughout the world. The most recent and main synthesis was by ICOLD [12] (221 tailings dam incidents), based on the previous database by USCOLD [13], which collected a large amount of information on incidents in the USA (185 tailings dam incidents) that occurred during the period 1917-1989. This database has been

supplemented by the U.S. Environmental Protection Agency [14] with recent mining and mineral processing damage cases in the USA and the United Nations Environmental Programme [15] (last updated 4 Mar 2006) in which a selection of 83 major tailings dam failures was compiled. The analysis of tailings dam performance provides important knowledge on key design factors on dam stability [12], including on site characteristics (geology, seismicity, climate, upstream catchment area), selection of embankment and construction sequence type, as well as hazard assessment (heavy rain, flooding, earthquake). Empirical models of dam failure impact and tailings outflow movement are more difficult to establish in a universal way due to the severe lack of reliable data from previous incidents and high levels of complexity on dam break mechanisms, breach size, water-tailings concentration and spilled volume.

The e-EcoRisk database (e-EcoRisk - A Regional Enterprise Network Decision-Support System for Environmental Risk and Disaster Management of Large-Scale Industrial Spills) was fed with the information mentioned above, after a process of revision, crosschecking and updating of the data using existing bibliographic sources. During this process, a detailed literature review was conducted to gather as much information on tailings dam failures as possible. New data were added and information gaps were completed using different data sources such as journals, conference proceedings, reports, published and unpublished dissertations and web pages [2,3,4,16,17,18,19,20, 21,22,23,24,25,26,27,28, among others]. Data from one of the European dams were obtained by interview with one dam failure witness and mine worker. The compilation 
of data from different European countries was achieved through the collaboration of the e-EcoRisk partners.

The reports on tailings dam failures are incomplete and heavily biased. There is no (complete) worldwide database of all historical failures. This database is, therefore, a subset of the actual number of tailings dam incidents in the world. The majority of tailings dam incidents remain unreported, especially in developing countries. In cases where a known accident did occur it is often difficult to access basic information regarding the tailings dam and its condition prior to the incident (e.g. dam height, tailings storage volume, tailings thickness, water content, etc). To date, 250 cases of tailings dam failures in the world have been compiled. For each case, as much information as possible was sought and documented. In the majority of cases, the information obtained is scarce; therefore, only 28 accidents (Table 1) with complete information on tailings outflow volume and flood run-out distance have been used in the correlation analysis presented in this study.

\section{RESULTS}

In water-storage dams, sensitivity studies have indicated that reservoir volume as well as dam height are critical factors in the magnitude of dam failure hydrographs $[9,29]$. The simplest proposed relations involve those two parameters, considering that most of the water volume stored at the reservoir was released. In the case of tailings ponds, the tailings outflow volume from dam incidents depends on the liquefaction process, break time, breach size and the amount of water content in the pond at the failure time. In most failure cases, tailings ponds are never emptied and, indeed, only a limited portion of the mine waste is released (see Table 1). Tailings outflow volume seems a more appropriate means to establish correlations with flood related parameters instead of reservoir volume. In tailings ponds, the height difference between the crest of the dam and the decant surface, known as freeboard, is rather small, and essentially the dam height equals the thickness of the tailings deposit. Accordingly, dam height provides a good approximation of the tailings thickness and its potential energy during the dam failure. 
In Fig. 1, a plot of dam height $(H)$ of the known historical tailings dam failures versus the outflow run-out distance $\left(D_{\max }\right)$ is shown. The graph shows a great dispersion of data and a poor relationship between these variables, described by the following regression equation:

$$
D_{\text {max }}=0.0528 \times H^{1.413} \quad r^{2}=0.16
$$

The envelope curve for run-out distance from all the tailings dams has the equation:

$$
D_{\max }=0.008 \times H^{3.23}
$$

This poor correlation shows that run-out distance depends on other factors not considered in the equation, such as outflow mine waste volume, gradient and topography to which tailings flood debouches.

A better relationship was obtained using mine waste outflow volume $\left(V_{F}\right)$, as the independent variable (note that $V_{F}$ includes tailings and water); although great data dispersion is still present (Fig. 2). A plot of these variables encompassing all the data points from Table 1 except case 8 (Churchrock, USA) provided the following regression equation:

$$
D_{\max }=14.445 \times V_{F}^{0.756} \quad r^{2}=0.56
$$

with a standard error (SE) of $0.62 \%$. The envelope curve obtained for this data set follows the equation:

$$
D_{\max }=112.61 \times V_{F}^{0.81}
$$

Data dispersion may be explained by the water content at the decant pond at the time of failure, the water/tailings ratio at the run-out flood, as well as the drainage slope.

The Churckrock dam (case 8) was an earthfill dam type located at a uranium mine. A major difference with other tailings dams is that the Churckrock dam retained only clear 
water and the outflow peak following the failure moved downstream a larger distance in relation to the dam height and outflow volume than conventional tailings dam failures. This indicates that this spill behaved in the manner of a water-storage dam failure and, accordingly, it was neither used in the regression equations (Eq. 3 and Eq. 5) nor on the envelope curves (Eq. 4 and Eq. 6). Other historic mine waste dam failures referred to in bibliographic sources as water-storage dams (WR in Table 1) at mine complexes have been marked on the different plots. These cases include dams from Cities Services (USA), Ollinghouse (USA) and Omai (Guyana) (cases 9, 21 and 22 in Table 1). Contrary to the Churchrock dam, these examples did contain tailings and so these case studies were included in Fig. 2.

In Fig. 1 (outflow run-out distance vs dam height) tailings ponds of water retention type (incident cases 8, 9, 21, 22 in Table 1) or containing a large volume of water at the failure time (incident cases 2, 5) are plotted close to the envelope curve, whereas those tailings ponds with lower water content plot in the lower part of the graph (incident cases 1, 13, 20, 25, 27 in Table 1). In Fig. 2 (outflow run-out distance vs mine waste outflow volume) data points are represented around a regression line which separate two data groups: (1) below the regression line data points correspond to incidents with a shorter tailings outflow run-out distance, and (2) above the line comprise those cases with a longer downstream dispersion of tailings outflow. The first group includes incidents with a high viscosity of the spilled mine waste (cases 3, 12, 13); a limitation on the tailings extent due to obstacles, topographic restrictions and barriers (cases 1, 23, 25); and those with very low slope gradient downstream of the pond. This is the case of Gypsum Tailings Dam (case 12) emplaced over a flat surface, containing non-plastic silt tailings with an average field water of about 30 percent [2]. In the case of Merriespruit dam, South Africa (case 18), a tailings spill of wet materials travelled $2 \mathrm{~km}$ before being halted and contained by an ornamental lake [30]. Other examples of a tailings release with short run-out distance is the Stancil dam (USA, case 25) where the tailings flowslide was blocked at a creek near the embankment toe [12].

The second cluster of data points (above regression line in Fig. 2) comprises those waste ponds which stored a larger volume of water with the tailings as well as those failures 
related to heavy rains and dam overtopping (cases 5, 14, 15, 17 in Table 1). Some examples includes La Patagua New Dam (case 15) and Los Maquis (case 17), both in Chile, where water contents of the tailings reached 70 and $85 \%$, respectively [19]. A different case is incident 28 (Unidentified, USA; Table 1) in which an anomalous tailings outflow volume (about one-third of the impoundment volume [12]) was reported, which apparently was not related to the large water volume stored behind the dam.

Hagen [9] and the Committee on the Safety of Existing Dams [31] developed a criteria for water-storage dams to estimate peak discharge based upon the product of the dam height $(H)$ and reservoir volume $(V)$, also known as dam factor $(H \times V)$. This factor is a crude index of the energy expenditure at the dam when it fails [10]. In most of the tailings dam incidents only a part of the pond volume was released, which is a major difference in behaviour with water-storage dam accidents. Therefore for tailings dams a better relationship was found when dam factor was based upon the tailings spilled volume $\left(V_{F}\right)$. In Fig. 3, a plot of a "tailings dam" factor $\left(H \times V_{F}\right)$ versus the outflow runout distance $\left(D_{\max }\right)$ is shown. The regression line including all the data except case 8 (Fig. 3) is the following:

$$
D_{\text {max }}=1.612 \times\left(H V_{F}\right)^{0.655} \quad r^{2}=0.57
$$

where $H$ is dam height in meters and $V_{F}$ is waste outflow volume in $10^{6} \mathrm{x} \mathrm{m}^{3}$.

An envelope curve encompassing all the historical tailings dam failures except case 8 has the equation:

$$
D_{\max }=12.46 \times\left(H V_{F}\right)^{0.79}
$$

A major limitation to the application of this equation to risk analysis of standing tailings dams consists of the uncertainty of potential tailings outflow volume $\left(V_{F}\right)$ in the case of failure. Another empirical relationship (Fig. 4) was found between the tailings storage volume and the tailings released at the incidents (using incident cases of Table 1), which has the equation 


$$
V_{F}=0.354 \times V_{T}^{1.008} \quad r^{2}=0.86
$$

The above equation shows, that in average, one third of the tailings and water at the decant pond is released during dam failures. The envelope curve represents the maximum tailings volume that can be released in the most extreme situation in which pond volume was emptied following the dam break, as is the case of water-storage dam accidents or those of industrial (diluted) waste ponds.

Available historic data on peak discharges from failures of tailings dams are scarce. In this study only three cases have been found: (1) from Buffalo Creek (USA; case 5), with an estimated discharge of $1415 \mathrm{~m}^{3} \mathrm{~s}^{-1}$ using the slope-area method [10]; (2) from Los Frailes (Spain; case 16), with a recorded discharge of $811 \mathrm{~m}^{3} \mathrm{~s}^{-1}$, using a rating curve obtained for clear water at a gauge station located $11 \mathrm{~km}$ downstream of the tailings dam [32]; and (3) from McLauren gold Mine (USA) [33], with an associated discharge of ca. $200 \mathrm{~m}^{3} \mathrm{~s}^{-1}$, estimated using the dam factor/discharge equation proposed by Costa [10].

On the basis of historical water-storage (constructed and natural) dam breaks, Costa [10] proposed several empirical relationships obtained using dam height $(H)$, water volume contained at the reservoir $(V)$ and the resulting flood peak discharge $(Q)$ when it failed (see Figs. 5 and 6). A major contribution of the Costa [10] paper is the analysis of floods from natural dams including ice dams (water impounded within or behind glacial ice), moraine dams, volcanic flow dams and landslide dams. Landslide dams typically involve large volumes of sediments producing wide abutments, which are partly eroded by water during dam overtopping and breaching [34]. According to Costa [10] this explains that flood peaks from failed landslide dams appear to be smaller than constructed dam failures with the same dam height and reservoir volume (Figs. 5 and 6). Similarly, when a tailings dam is overtopped by runoff excess from the drainage basin, there is commonly large water content for tailings sediment before a full breach is developed which would be added to the tailings outflow volume. A tailings flood is commonly composed of water with high sediment concentration which provides a wide 
range of fluid behavior from debris flow to muddy floodwater. This wide range of flow behavior is reflected in the representation of the few available historical data points (Fig. 5 and 6), which corresponds to Buffalo Creek (case 5) and Los Frailes (case 16). On the one hand, Buffalo Creek dam incident plots on the regression line corresponding to water-storage dams due to a dam failure caused by flow overtopping in relation to extreme rainfall. The run-out flood contained a mixture of water and carbon residua with a turbulent flow behavior [2], which indeed plots on the regression line of incidents related to constructed earthfill dams for water-storage. Regarding Los Frailes tailings dam incident, it was released a high viscous flow containing a large proportion of tailings. The mine waste flood discharge was recorded at a gauge station located $11 \mathrm{~km}$ downstream of the tailings dam. The hydrograph shape comprised two peaks, with the first one reaching $811 \mathrm{~m}^{3} \mathrm{~s}^{-1}$ and a second one of $294 \mathrm{~m}^{3} \mathrm{~s}^{-1}$, according to a rating curve calibrated for water flow, which probably overestimated the mine waste discharge due to its higher viscosity [32]. The first hydrograph peak was composed of a waterdominant flow, mainly from the upper water-laid layer at the reservoir, whereas the second contained a high tailings load in a high viscosity flow (Fig. 7). As shown in Fig. 5, Los Frailes tailings dam incident (case 16) plots on the regression line obtained from historical failures of landslide dams after Costa [10]. The discharge estimation from the landslide dam failure equation is $1189 \mathrm{~m}^{3} \mathrm{~s}^{-1}$, which is a similar order of magnitude to the the $811 \mathrm{~m}^{3} \mathrm{~s}^{-1}$ recorded at the gauge station for the first hydrograph peak [32].

Fig. 6 shows the empirical relationship between dam factor and peak discharge of historical dam failures of constructed and natural dams by Costa [10], in which dam factor $(H \times V)$ for Los Frailes tailings dam failure was plotted using both the total tailings volume stored at the decant pond (case 16 point 2) and the outflow volume (case 16 point 1). It is shown that for tailings dam failures more robust results are obtained considering the spilled tailings volume than the ones applying the total tailings volume contained at the reservoir when dam failed.

\section{DISCUSSION}


In this paper, empirical relationships of mine decant pond geometric characteristics with hydrologic parameters of floods from mine waste spills from historic dam failures were obtained. These relationships provide a first approximation to estimate the tailings outflow volume and the mine waste run-out distance from a dam failure, although these assessments may contain large uncertainties considering the high standard errors of the regression equations. These errors result from a large variety of parameters affecting the mine waste flow, including sediment load, fluid behavior (Newtonian or Binghamplastic) which depends on the type of failure (e.g. seismic action, static liquefaction, slide, etc), particle-dependent rheology of the suspension, topography and valley gradient and presence of obstacles impeding the slurry to flow among others. Other source of uncertainty is related to the lack of data related with the water volume existing at the time of failure either stored at the decant pond or linked to the meteorological causes triggering the dam failure (intense rainfall, hurricanes, rapid snowmelt, ice accumulation in the tailings dam, etc), which may change indeed the hydrologic conditions (peak discharge, tailings outflow volume) and the run-out distance of the tailings. Those conditions are site and event specific and therefore difficult to be considered by empirical relationships.

These uncertainties may be reduced considering the most similar case in the historical database. This analysis can also be used as a deterministic tool to provide information on the largest peak discharge and/or potential distance of the tailings flood by using the proposed envelope curves. Note that even in this case, a greater distance may be reached if the released tailings is mixed and diluted within a river water flow, as happened in various historical tailings dam incidents. In spite of the described limitations, the method provides preliminary data on the tailings outflow hydraulic characteristics using basic available tailings dam and embankment parameters, which may be used, for instance, to classify the failure risk associated to a large population of tailings dams.

These equations were applied on two case studies of the e-Ecorisk project (Table 2): (1) Los Frailes dam (Aznalcollar, Spain, case 16, Table 1) which failed in April, 1998; and (2) the inactive Ashes Dam at the Almagrera mine (Spain), an example of an unbreached tailings dam.On 25 April 1998, the rupture of the dam containing the tailings 
reservoir of the pyrite mine of Aznalcóllar caused a spill of $4.5 \times 10^{6} \mathrm{~m}^{3}$ of acid water and pyrite ore. The resulting mine waste, containing high concentrations of heavy metals (mean particle size $12 \mu \mathrm{m}$ ), was of a solid content of some $0.88 \times 10^{6} \mathrm{~m}^{3}$ and $2.97 \times 10^{3} \mathrm{Mg}$ mass [6]. The accident provoked the inundation of the floodplains of the rivers Agrio and Guadiamar (average stream gradient of 0.00146) and was close to affecting the Guadalquivir marshlands posing a substantial threat to the ecosystems of the Doñana Natural and National Parks. The tailings flood led to the sedimentation of pyrite contaminated waste [35, 36] along the floodplain of the Agrio- Guadiamar system, covering 2616 ha from the failed dam to the start of the Guadalquivir marshlands. Heavy metal pollution (zinc, lead, and cadmium among others; [37]) mostly affected the superficial soil layers $(0-20 \mathrm{~cm})$, although in some coarser soils pollution may penetrate down to at least $50-80 \mathrm{~cm}$ [38].

The empirical regression equations proposed in this study provide an estimation of mine waste outflow volume ranging between 5.4-7.3 x $10^{6} \mathrm{~m}^{3}$ (from equation 7; Table 3), whereas the actual Aznalcollar incident released $4.6 \times 10^{6} \mathrm{~m}^{3}$ which includes acid water and pyrite ore. The mine waste run-out distance estimated from equation 5 ranges between 42 and $51 \mathrm{~km}$ (Table 3). The actual run-out distance downstream of the Guadiamar river was between 40 and 45 km (according to Antón-Pacheco et al. [39]), which is similar to the empirically estimated tailings outflow travel distance.

The Almagrera mine, the second test case, is within the same metalogenetic province and mining context of the Aznalcollar mines. At the Almagrera mine, the ashes dam is $34.5 \mathrm{~m}$ in height with an actual tailings volume of $2.8 \times 10^{6} \mathrm{~m}^{3}$, although it was designed to store about $3.2 \times 10^{6} \mathrm{~m}^{3}$ of milled waste [40]. In the case of dam failure, the proposed empirical regression lines show an estimated run-out distance between 16 and $32 \mathrm{~km}$ (Table 3) for present conditions (volume stored of $2.8 \times 10^{6} \mathrm{~m}^{3}$ ). The Almagrera dam is connected with a tributary stream which joins the Odiel River (stream gradient $0.00154)$ ca. $3.5 \mathrm{~km}$ downstream. According to this estimated run-out distance, the tailings waste may reach the Odiel River and pollutants can be dispersed by the river's stream flow, in a similar way to the Aznacollar incident. 
The proposed equations should be considered as a first approach in tailings dam risk studies, but more precise deterministic models are required to provide precise site by site tailings flood impacts. Errors may be large on extreme cases either for tailings dam containing high water volume, or for hyperconcentrated flows. Obstacles or barriers along the slurry pathway should also be considered. On the positive side, there is a lack of detailed data on most of the existing tailings dams of the world. In addition, for operative tailings dams is not possible to anticipate the volume of water that may be involved or the thickness of the tailings contained at the decant pond at time of failure. In those cases, basic dam information (dam height and volume), which can be obtained from national dam databases or by remote sensing analysis, may provide preliminary data to assess potential risk to downstream socio-economic activities and environmental impacts.

\section{CONCLUSIONS}

Dam failure impact depends on the tailings outflow travel distance and path, and on the exposure and vulnerability of goods, population, land use, water use and environmental values of the natural areas located downstream. The diversity of the tailings dam characteristics (dam type, dam situation, type of sequentially raised tailing dam, dam foundation, dam fill material, state of activity, storage volume, tailings dam height, tailings' density and pond water volume, among others), make any universal prediction assessing dam failure impacts very speculative. In addition, detailed risk assessments involve timely and costly geotechnical, hydrological and hydraulic studies which can only be completed with either or both the complicity of mining companies and political authorities.

In this study, a worldwide database of historic failures was collected from which a regression analysis was carried out in order to establish relationships and trends. The resulting empirical correlations among physical parameters (namely dam height and pond volume) of the tailings reservoir and tailings flood characteristics can be applied to provide a first estimate on the volume of tailings spills, tailings run-out distance and, with the appropriate measurements and observations, even to assess the outflow peak discharge. In these relationships, two possible solutions have been provided: (1) a 
conservative estimation based on the regression equations of the historic tailings dam failures; and (2) the worst case scenario estimation based on the envelope curves developed from historic dam failures from tailings dams and water retention dams.

Tailings outflow volume from a dam failure can be reasonably estimated if total tailings pond volume is known. Then, the estimated tailings spill can be used in combination with the dam factor (height and volume) and the pond's tailings volume for prediction purposes on the estimation of run-out distance of standing dams. Two case studies included in the European Commission e-Ecorisk project, namely the Los Frailes (Aznalcollar) historic dam failure and the standing tailings dam at Almagrera (Ashes dam) complex have been discussed in view of the results provided by the proposed regression equations. It is evident that the results need to be treated with caution, due to the uncertainty present in documentary evidence and the diversity of the tailings dams. However, the estimates obtained for the Aznacollar dam failure provided similar values in terms of tailings outflow volume and run-out distance to the field observations. In summary, the proposed regression equations provide a first approach to assess some risk parameters at dams with a lack of information or prior to further detailed studies.

\section{ACKNOWLEDGMENTS}

The authors are very grateful to Varyl Thorndycraft for the critical review of the original manuscript, and for his very useful comments and suggestions. This research has been funded by the European Commission through the project "A regional enterprise network decision-support system for environmental risk and disaster management of large-scale industrial spills”, e-Ecorisk Project (contract no. EVG12002-0068) and by the Spanish Ministry of Science and Education (HP2006-0072).

\section{REFERENCES}

[1] J.K. Jeyapalan, J.M. Duncan, H.B. Seed, Summary of research on analyses of flow failures of mine tailings impoudments. Information Circular 8857, Technology Transfer Workshop on Mine Waste Disposal Techniques, U.S. Bureau of Mines, Denver, Colorado, 1981, pp. 54-61.

[2] J.K. Jeyapalan, J.M. Duncan, H.B. Seed, Investigation of flow failures of tailings dams, Journal of the Geotechnical Engineering Division 109(2) (1983) 172-189. 
[3] G.E. Blight, Destructive mudflows as a consequence of tailings dyke failures. Proc. Inst. Civ. Eng. 125 (1997) 9-18.

[4] F.v.M. Wagener, H.J. Craig, G. Blight, G. McPhail, A.A.B. Williams, J.H. Strydom, The Merriespruit tailings dam failure, in: Tailings and Mine Waste 1998, Proceedings of the Fifth International Conference on Tailings and Mine Waste 1998, Fort Collins, Colorado, USA, 26-28 January 1998, Balkema, Rotterdam, 1998, pp. 925-952 .

[5] CMA. El accidente minero de Aznalcóllar. Medio ambiente en Andalucía, Informe 1998, Consejería Medio Ambiente (Junta Andalucía), Sevilla, 1998.

[6] F. Gallart, G. Benito, J.P. Martín Vide, A. Benito, J.M. Prió, D. Regüés, Fluvial geomorphology and hydrology in the dispersal and fate of pyrite mud particles released by the Aznalcóllar mine tailings spill. The Science of the Total Environment 242 (1999) 13-26.

[7] G. Benito, A. Benito-Calvo, F. Gallart, J.P. Martín-Vide, D. Regüés, E. Bladé, Hydrological and geomorphological criteria to evaluate the dispersion risk of waste slurry generated by the Aznalcollar mine spill (SW Spain). Environmental Geology 40(4/5) (2001) 417-428.

[8] G.W. Kirkpatrick, Evaluation guidelines for spillway adequacy, in: The Evaluation of Dam Safety, Proceedings of the Engineering Foundation Conference, Am. Soc. Civ. Eng., New York, 1977, pp. 395-414.

[9] V.K. Hagen, Re-evaluation of design floods and dam safety, in: Proceedings of the 14th International Congress on Large Dams, vol.1, Commission on Large Dams Congress, Rio de Janeiro, 1982, pp.275-491.

[10] J.E. Costa, Floods from dam failures, in: V.R. Baker et al. (Eds.), Flood Geomorphology, Wiley, New York, 1988, pp. 439-463.

[11] P.C. Lucia, J.M. Duncan, H.B. Seed, Summary of research on case histories of flow failures of mine tailings impoundments, in: Technology Transfer Workshop on Mine Waste Disposal Techniques, Information Circular 8857, U.S. Bureau of Mines, Denver, Colorado, 1981, pp. 46-53.

[12] ICOLD. Tailings Dams - Risk of dangerous occurrences, lessons learnt from practical experiences, Bulletin 121, United Nations Environmental Programme (UNEP), Division of Technology, Industry and Economics (DTIE) and International Commission on Large Dams (ICOLD), Paris, 2001.

[13] USCOLD. Tailings Dam Incidents, U.S. Committee on Large Dams (USCOLD), Denver, Colorado, 1994.

[14] EPA. Damage Cases and Environmental Releases from Mines and Mineral Processing Sites, U.S. Environmental Protection Agency, Office of Solid Waste, Washington DC, 1997.

[15] UNEP. Environmental and safety incidents concerning tailings dams at mines: results of a survey for the years 1980-1996 by the Mining Journal Research Services, Report prepared for United Nations Environment Programme, Industry and Environment, Paris, 1996. 
[16] S.C. Bourcy, R.E. Weeks, Stream morphology and habitat restoration of Pinto Creek, Gila County, Arizona, in: Tailings and Mine Waste 2000, Proceedings of the Seventh International Conference on Tailings and Mine Waste 2000, Fort Collins, Colorado, USA, 23-26 January 2000, Balkema, Rotterdam, 2000, pp. 467475.

[17] D. Brink, The long-term repair of the Merriespruit Tailings Dam, in: Tailings and Mine Waste 1998, Proceedings of the Fifth International Conference on Tailings and Mine Waste 1998, Fort Collins, Colorado, USA, 26-28 January 1998, Balkema, Rotterdam, 1998, pp. 953-957.

[18] R.J. Chandler, G. Tosatti, The Stava tailings dams failure, Italy, July 1985, Proc. Inst. Civ. Eng. 113 (1995) 67-79.

[19] R. Dobry, L. Alvarez, Seismic failures of Chilean tailings dams, Journal of the Soil Mechanics and Foundations Division 93 (1967) 237-260.

[20] A.B. Fourie, G. Papageorfiou, G.E. Blight, Static liquefaction as an explanation for two catastrophic tailings dam failures in South Africa, in: Tailings and Mine Waste 2000, Proceedings of the Seventh International Conference on Tailings and Mine Waste 2000, Fort Collins, Colorado, USA, 23-26 January 2000, Balkema, Rotterdam, 2000, pp. 149-158.

[21] L.A. Hansen, N.J. LaFronz, M.B. Yasin, Stabilization of the Pinto Valley tailings impoundment slide, in: Tailings and Mine Waste 2000, Proceedings of the Seventh International Conference on Tailings and Mine Waste 2000, Fort Collins, Colorado, USA, 23-26 January 2000, Balkema, Rotterdam, 2000, pp. 477-487.

[22] R.N. Kostaschuk, J.M.T. Wilkinson, Predicting the deformation of tailings dams resulting from earthquake liquefaction, in: Tailings and Mine Waste 1999, Proceedings of the Sixth International Conference on Tailings and Mine Waste 1999, Fort Collins, Colorado, USA, 24-27 January 1999, Balkema, Rotterdam, 1999, pp. 237-248.

[23] L.F. Harder, J. P. Stewart, Failure of Tapo Canyon Tailings Dam. Journal of Performance of Constructed Facilities 10(3) (1996) 109-114.

[24] G. McPhail, R.J. Stuart, D. Venter, The disaster of Merriespruit and its consequences: remediation-making safe, in: Tailings and Mine Waste 1998: proceedings of the Fifth International Conference on Tailings and Mine Waste 1998, Fort Collins, Colorado, USA, 26-28 January 1998, Balkema, Rotterdam, 1998, pp. 959-957.

[25] D.J. Miller, Failure modes and effects analyses of potential ground movements at Golden Sunlight Mine, in: Tailings and Mine Waste 1999, Proceedings of the Sixth International Conference on Tailings and Mine Waste 1999, Fort Collins, Colorado, USA, 24-27 January 1999, Balkema, Rotterdam, 1999, pp. 335-344.

[26] A.D. Penman, Risk analyses of tailings dam construction, in: Conference proceedings: Safety of Mining Dams Seminar, Gällivare, 20-21 September 2001, Swedish Mining Association, Natur Vards Verket, European Commission, Technical Papers, 2001, pp. 37-53. 
[27] H.J. Van Niekerk, M.J. Viljoen, Causes and consequences of the Merriespruit and other tailings-dam failures, Land degradation \& development 16 (2005) 201-212

[28] M. Willow, C. tenBraak, Survey of three hard-rock acid drainage treatment facilities in Colorado, in: Tailings and Mine Waste 1999, Proceedings of the Sixth International Conference on Tailings and Mine Waste 1999, Fort Collins, Colorado, USA, 24-27 January 1999, Balkema, Rotterdam, 1999, pp. 759-767.

[29] A.W. Petrascheck, P.A. Sydler, Routing of dam break floods, International Water Power and Dam Construction 36 (1984) 29-32.

[30] G.E. Blight, A.B. Fourie, A review of catastrophic flow failures of deposits of mine waste and municipal refuse. Introductory report of the International Workshop on Occurrence and mechanisms of flows in natural slopes and earthfills, IWFLOWS2003, Sorrento, Italy, 14-16 May 2003, Associazione Geotecnica Italiana (AGI), 2003. (http://www.unina2.it/flows2003/flows2003/articoli/articoli.htm).

[31] Committee on the Safety of Existing Dams. Safety of existing dams: evaluation and improvement. National Academy Press, Washington D.C., 1983.

[32] F. Ayala-Carcedo, La rotura de la balsa de residuos mineros de Aznalcóllar (España) de 1998 y el desastre ecológico consecuente del río Guadiamar: causas, efectos y lecciones, Boletín Geológico y Minero 115(4) (2004) 711-738.

[33] W.A. Marcus, G.A. Meyer, D.R. Nimmo, Geomorphic control of persistent mine impacts in a Yellowstone Park stream and implications for the recovery of fluvial systems, Geology 29 (4) (2001) 355-358.

[34] K.L. Lee, J.M. Duncan, Landslide of April 25, 1974 on the Mantaro River, Peru. National Academy of Sciences, Washington, D.C., 1975.

[35] E. López-Pamo, D. Barettino, C. Antón-Pacheco, G. Ortiz, J.C. Arránz, J.C. Gumiel, B. Martínez-Pledel, M. Aparicio, O. Montouto, The extent of the Aznalcóllar pyritic slurry spill and its effects on soils, The Science of the Total Environment 242(1-3) (1999) 57-88.

[36] ITGE. Cartografía y cubicación de lodos mineros en la cuenca del río Guadiamar. Aznalcollar-Entremuros. Internal report, RM-001-98, Instituto Tecnológico Geominero de España (ITGE), Madrid, 1998.

[37] J.O. Grimalt, M. Ferrer, E. Macpherson, The mine tailing accident in Aznalcollar, The Science of the Total Environment 242 (1999) 3-11.

[38] F. Cabrera, L. Clemente, E. Díaz Barrientos, R. López, J.M. Murillo, Heavy metal pollution of soils affected by the Guadiamar toxic flood, The Science of the Total Environment 242 (1999) 117-129.

[39] C. Antón-Pacheco, J.C.Arranz, D. Barettino, G. Carrero, M. Giménez, J.A. Gómez, J.C. Gumiel, E. López-Pamo, J.A. Martín Rubí, B. Martínez Pledel, E. De Miguel, J. Moreno, G. Ortiz, J.G. Rejas, A. Silgado, E. M. Vázquez, Actuaciones para el reconocimiento y retirada de los lodos depositados sobre el terreno, y su restauración edáfica y morfológica. Mapping and removal of the sludge deposited on land. Soil remediation and morphological restoration of the fluvial system. Boletín Geológico y Minero 112 (Special issue) (2001) 93-122. 
[40] Knight Piésold Consultiong. Almagrera S.A. Normas de Seguridad Estructural y Plan de Emergencia. ITC 08.02.01 de 22 de Abril de 2000. Depósito de estériles. Depósitos de cenizas (Internal report), Huelva, 2001. 
Table 1. Historical tailings dam failures used in the correlation analysis. Legend: RING: Ring dyke; WR: Water Retention; UPS: Dams subsequently raised upstream; MXSQ: Dam comprising different raising typology (upstream, centreline and downstream); $H$ : Dam height; $V_{F}$ : Volume of tailings released.

\begin{tabular}{|c|c|c|c|c|c|c|c|c|}
\hline $\begin{array}{l}\text { Ref. } \\
\mathrm{N}^{\circ} \text {. }\end{array}$ & Name of the Dam & $\begin{array}{l}\text { Date of } \\
\text { failure } \\
\text { (year) }\end{array}$ & $\begin{array}{l}\text { Type of } \\
\text { dam }\end{array}$ & $\begin{array}{l}\text { Dam } \\
\text { Height } \\
\text { (m) }\end{array}$ & $\begin{array}{c}\text { Impoudment } \\
\text { volume } \\
\left(\mathrm{x} 10^{6} \mathrm{~m}^{3}\right) \\
\end{array}$ & $\begin{array}{c}\text { Run-out } \\
\text { Distance } \\
(\mathrm{km}) \\
\end{array}$ & $\begin{array}{c}\text { Dam } \\
\text { Factor } \\
\left(H x V_{F}\right) \\
\end{array}$ & $\begin{array}{c}\text { Released } \\
\text { Volume } \\
\left(\mathrm{x} 10^{6} \mathrm{~m}^{3}\right) \\
\end{array}$ \\
\hline 1 & "Arcturus (Zimbawe ) & 1978 & 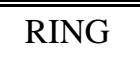 & 25 & $1.7-2.0 \mathrm{Mt}$ & 0.3 & 0.5 & 0.0211 \\
\hline 2 & Bafokeng (South Africa) & 1974 & RING & 20 & 13 & 45 & 60 & 3 \\
\hline 3 & Baia Mare (Romania) & 2000 & UPS & 7 & 0.8 & 0.18 & 0.7 & 0.1 \\
\hline 4 & Bellavista (Chile) & 1965 & RING & 20 & 0.45 & 0.8 & 1.4 & 0.07 \\
\hline 5 & Buffalo Creek (USA) & 1972 & UPS & $14-18$ & 0.5 & 64.4 & $7-9$ & 0.5 \\
\hline 6 & Cerro Negro No.3 (Chile) & 1965 & UPS & 20 & 0.5 & 5 & 1.7 & 0.085 \\
\hline 7 & Cerro Negro No.4 (Chile) & 1985 & MXSQ & 40 & 2 & $\begin{array}{c}8 \\
96.5-\end{array}$ & 20 & 0.5 \\
\hline 8 & Churchrock (USA) & 1979 & WR & 11 & 0.37 & 112.6 & 4.07 & 0.37 \\
\hline 9 & Cities Service (USA) & 1971 & WR & 15 & 12.34 & 120 & 135 & 9 \\
\hline 10 & El Cobre Old Dam (Chile) & 1965 & UPS & 35 & 4.25 & 12 & 66.5 & 1.9 \\
\hline 11 & $\begin{array}{l}\text { Galena Mine (USA) } \\
\text { Gypsum Tailings Dam }\end{array}$ & 1974 & UPS & 9 & & 0.61 & $\begin{array}{l}0.034 \\
0.88-\end{array}$ & 0.0038 \\
\hline 12 & (USA) & 1966 & UPS & 11 & $7 \mathrm{Mt}$ & 0.3 & 1.43 & $2 \times 10^{5} \mathrm{t}$ \\
\hline 13 & Hokkaido (Japan) & 1968 & UPS & 12 & 0.3 & 0.15 & 1.08 & 0.09 \\
\hline 14 & Itabirito (Brazil) & 1986 & Gravity & 30 & & 12 & 3 & 0.1 \\
\hline 15 & La Patagua New Dam (Chile) & 1965 & RING & 15 & & 5 & 0.525 & 0.035 \\
\hline 16 & Los Frailes (Spain) & 1998 & RING & 27 & $15-20$ & 41 & 53.51 & 4.6 \\
\hline 17 & Los Maquis (Chile) & 1965 & UPS & 15 & 0.043 & 5 & 0.315 & 0.021 \\
\hline 18 & Merriespruit (South Africa) & 1994 & RING & 31 & 7.04 & 2 & 18.6 & $2.5 \mathrm{Mt}$ \\
\hline 19 & Mochikoshi No.1 (Japan) & 1978 & UPS & 28 & 0.48 & 8 & 2.24 & 0.08 \\
\hline 20 & Mochikoshi No.2 (Japan) & 1978 & UPS & 19 & & 0.15 & 0.057 & 0.003 \\
\hline 21 & Ollinghouse (USA) & 1985 & WR & 5 & 0.12 & 1.5 & 0.125 & 0.025 \\
\hline 22 & Omai (Guyana) & 1995 & WR & 44 & 5.25 & 80 & 184.8 & 4.2 \\
\hline 23 & Phelps-Dodge (USA) & 1980 & UPS & 66 & 2.5 & 8 & 132 & 2 \\
\hline 24 & Sgurigrad (Bulgaria) & 1966 & UPS & 45 & 1.52 & 6 & 9.9 & 0.22 \\
\hline 25 & Stancil (USA) & 1989 & UPS & 9 & 0.074 & 0.1 & 0.342 & 0.038 \\
\hline 26 & Stava (Italy) & 1985 & RING & 29.5 & 0.3 & 4.2 & 5.605 & 0.19 \\
\hline 27 & Tapo Canyon (USA) & 1994 & UPS & 24 & & 0.18 & & \\
\hline 28 & Unidentified (USA) & 1973 & UPS & 43 & 0.5 & 25 & 7.31 & 0.17 \\
\hline 29 & Veta del Agua $\mathrm{N}^{\circ} 1$ (Chile) & 1985 & MXSQ & 24 & 0.7 & 5 & 6.72 & 0.28 \\
\hline
\end{tabular}


Table 2. Tailings dam characteristics of the selected examples, and channel slope of the major river connected to the tailings pond.

\begin{tabular}{lccc}
\hline Dam name & Dam Height & $\begin{array}{c}\text { Tailings } \\
\text { volume at } \\
\text { decant pond } \\
\left(\mathrm{x} 10^{6} \mathrm{~m}^{3}\right)\end{array}$ & $\begin{array}{c}\text { Average } \\
\text { slope } \\
\text { downstream } \\
\mathrm{m} \mathrm{m}^{-1}\end{array}$ \\
\hline Los Frailes Dam (Spain) & 27 & $15-20$ & 0.00146 \\
Almagrera Ashes Dam (Spain) & 34.5 & 2.8 & 0.00154 \\
\hline
\end{tabular}


Table 3. Tailings volume for different dams, and observed spilled volume and distance run-out of tailings in relation to the Los Frailes (Aznalcollar) dam incident. $V_{T}$ : Total tailings volume at dam. $V_{F}$ : Tailings outflow volume; $D$ : Run-out distance of tailings following dam breach. Tailings outflow volume and pollutant run-out distance were estimated using equations 7 and 5. *Note that tailings spill volume includes acid water and pyrite ore.

\begin{tabular}{lcccccc}
\hline & $\begin{array}{c}V_{T} \\
\left(\mathrm{x} 10^{6} \mathrm{~m}^{3}\right)\end{array}$ & $\begin{array}{c}V_{F} \\
\text { observed } \\
\left(\mathrm{x} 10^{6} \mathrm{~m}^{3}\right)\end{array}$ & $\begin{array}{c}V_{F}{ }^{\prime} \text { from } \\
\text { eq.7 } \\
\left(\mathrm{x} 10^{6} \mathrm{~m}^{3}\right)\end{array}$ & $\begin{array}{c}D \\
\text { observed } \\
(\mathrm{km})\end{array}$ & $\begin{array}{c}D(\mathrm{~km}) \text { estimated } \\
\text { from eq. 5 using : } \\
V_{T}\end{array}$ & $V_{F}{ }^{\prime}$ \\
\hline \hline $\begin{array}{l}\text { Lam name Frailes Dam (case } \mathrm{n}^{0} \\
\begin{array}{l}16 \text { in Table 1) } \\
\text { Almagrera Ashes Dam }\end{array}\end{array}$ & $15-20$ & $4.6^{*}$ & $5.4-7.3$ & 41 & $82-99$ & $42-51$ \\
\hline
\end{tabular}




\section{FIGURE CAPTIONS}

Figure 1. Graph showing the dam height ( $H$ in metres) at time of failure, versus the run-out distance of tailings following dam breach $\left(D_{\max }\right.$ in $\left.\mathrm{km}\right)$ for the historical failure cases, with numbers keyed to Table 1.

Figure 2. Graph showing the tailings outflow volume due to tailings dam incidents $\left(V_{F}\right.$, in millions of cubic metres) versus the run-out distance of tailings from historical failure cases $\left(D_{\max }\right.$ in $\left.\mathrm{km}\right)$, with numbers referred in Table 1.

Figure 3. Graph showing "tailings dam" factor $\left(H \times V_{F} ; H\right.$ in metres and $V_{F}$ in $\left.10^{6} \mathrm{x} \mathrm{m}^{3}\right)$ versus run-out distance of tailings ( $D_{\max }$ in $\mathrm{km}$ ) for the historical failure cases, with numbers keyed to Table 1.

Figure 4. Graph showing the tailings outflow volume from the tailings dam $\left(V_{F}\right.$ in $\left.10^{6} \mathrm{x} \mathrm{m}^{3}\right)$ versus the volume of tailings stored at the dam $\left(V_{T}\right.$ in $\left.10^{6} \mathrm{x} \mathrm{m}^{3}\right)$ at the time of the incident.

Figure 5. Graph the dam height ( $H$ in metres) at time of failure, versus peak discharge $\left(\mathrm{m}^{3} \mathrm{~s}^{-1}\right)$ for constructed and landslide dams (dates from Costa [10]) and tailings dams (case 5: Buffalo Creek, USA; case 16: Los Frailes, Aznalcollar, Spain).

Figure 6. Graph the dam factor $(H \times V)$ versus peak discharge $\left(\mathrm{m}^{3} \mathrm{~s}^{-1}\right)$ for constructed and landslide dams (data from Costa [10]) and tailings dams (Case 5: Buffalo Creek, USA; Case 16: Los Frailes, Aznalcollar, Spain. (numbers keyed to Table 1). Dam factor ( $H x V)$ for Los Frailes was plotted using both the total tailings volume at decant pond (case 16 point 2) and the tailings outflow volume (case 16 point 1). In the Aznacollar incident, a discharge-dam factor relationship similar to landslide dams is obtained from a dam factor calculated from the spilled tailings volume instead of the total dam tailings volume which is used on water-retention dam failures relationships.

Figure 7. Slurry flood hydrograph of the Aznacollar spill in the El Guijo gauge station, $11 \mathrm{~km}$ downstream of the Los Frailes tailings dam, in the Guadiamar river. The hydrograph comprises two peaks related to a first water pulse and a second tailings flow. (after Ayala-Carcedo [32]). 


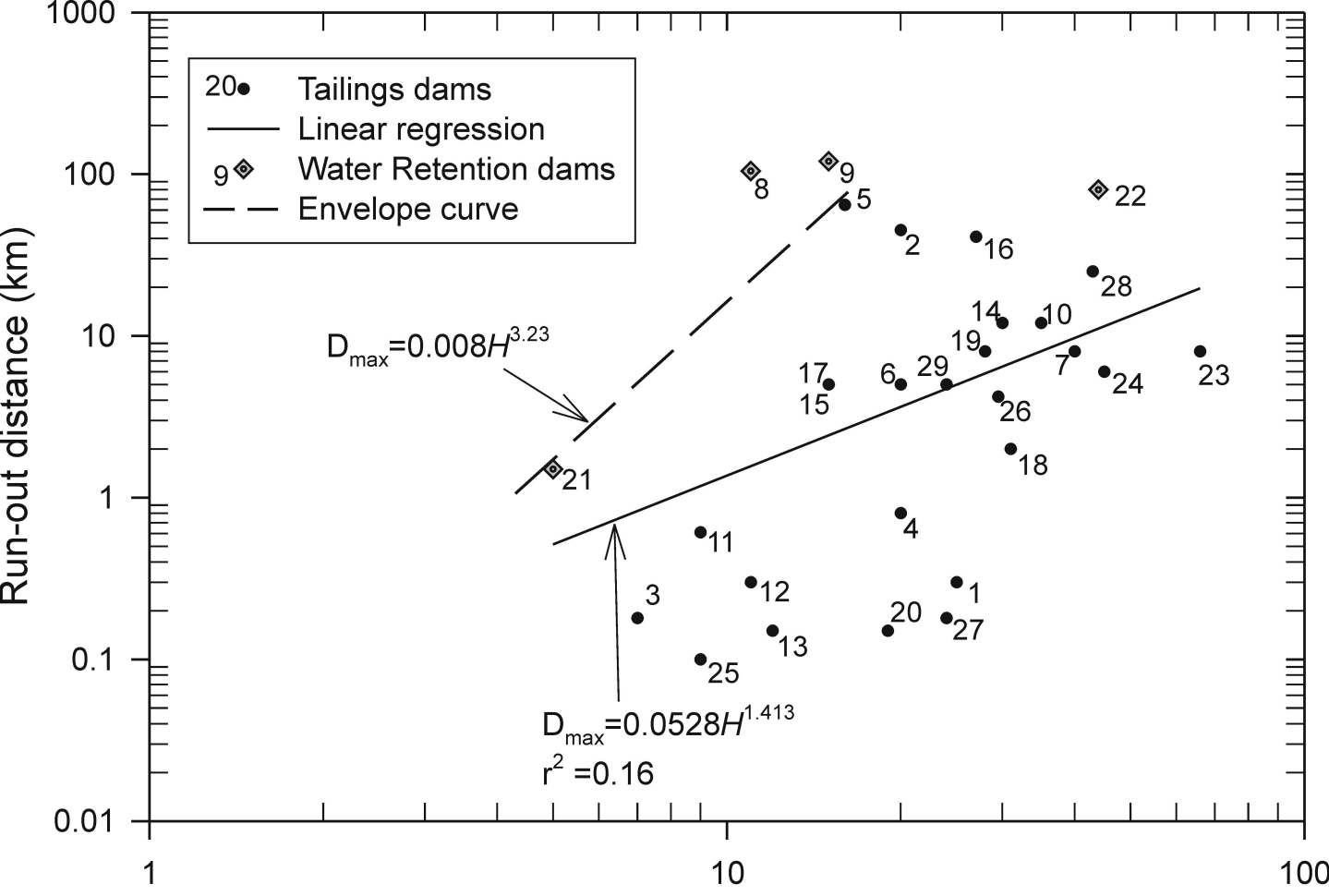

Dam Height (m) 


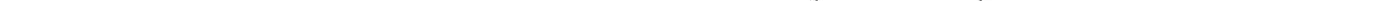




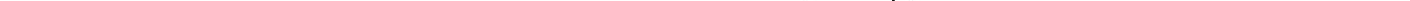




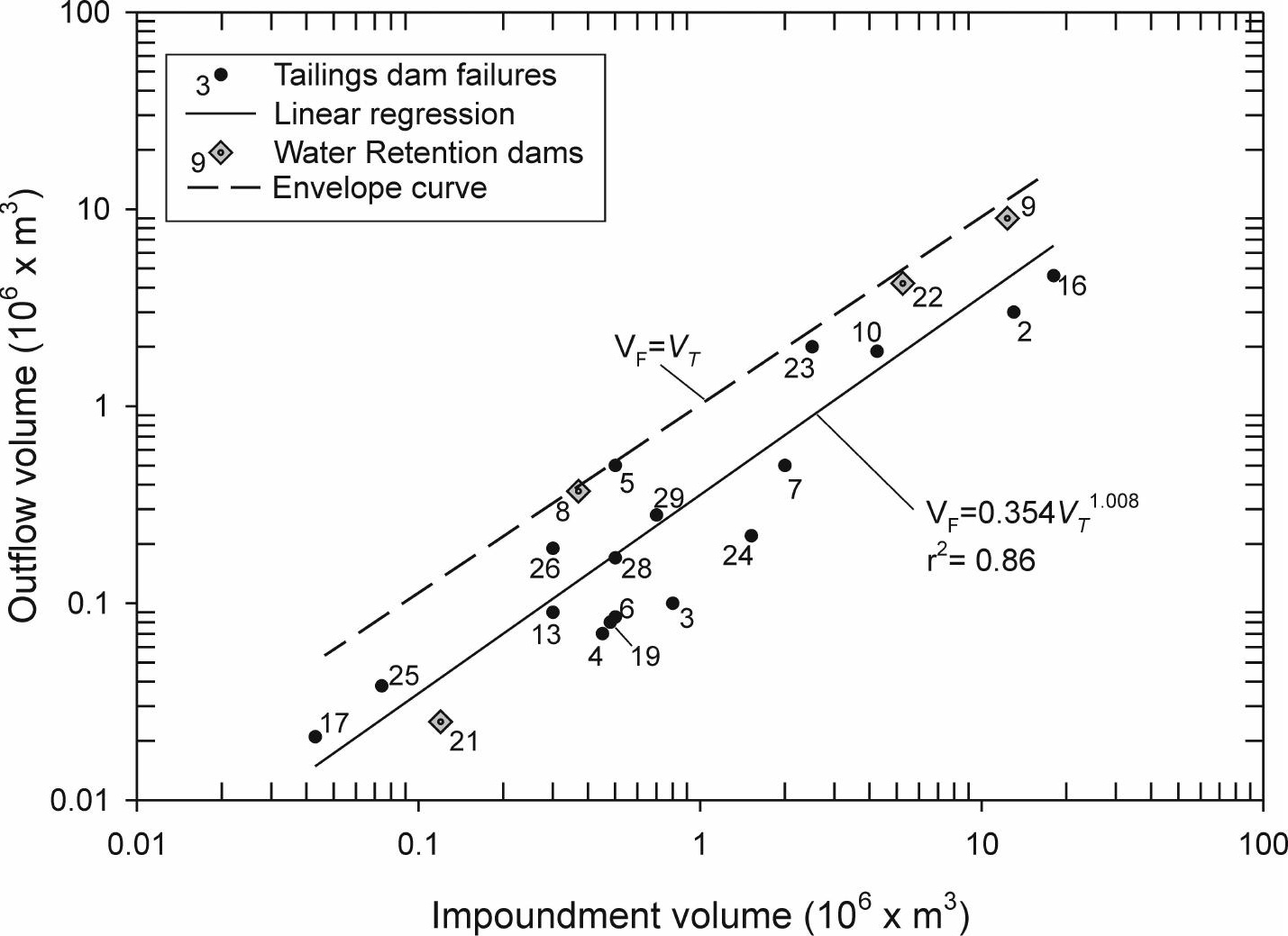




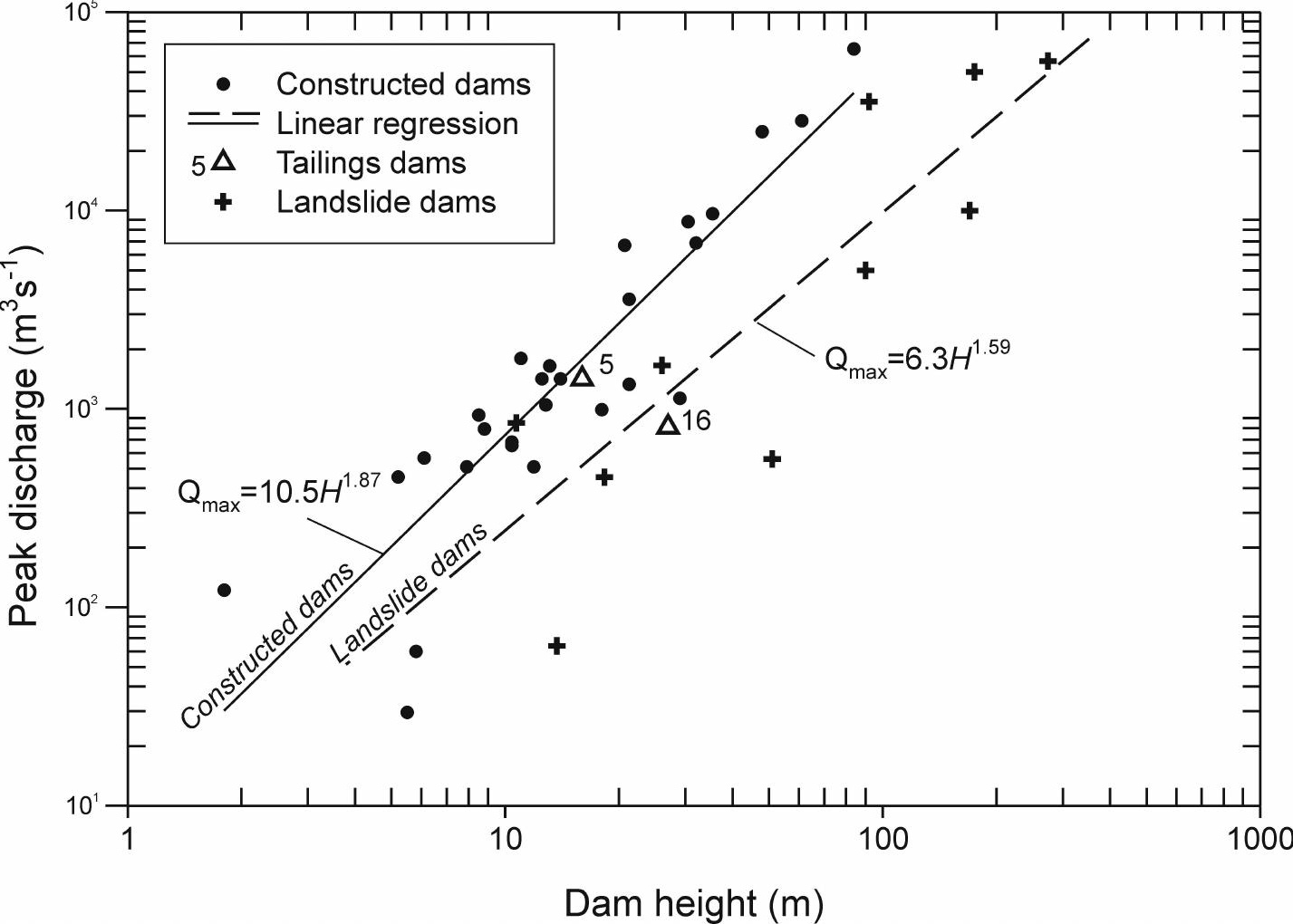




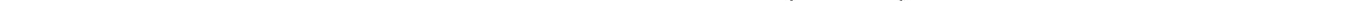




\section{TAILINGS FLOOD HYDROGRAPH IN THE EL GUIJO GAUGE STATION}

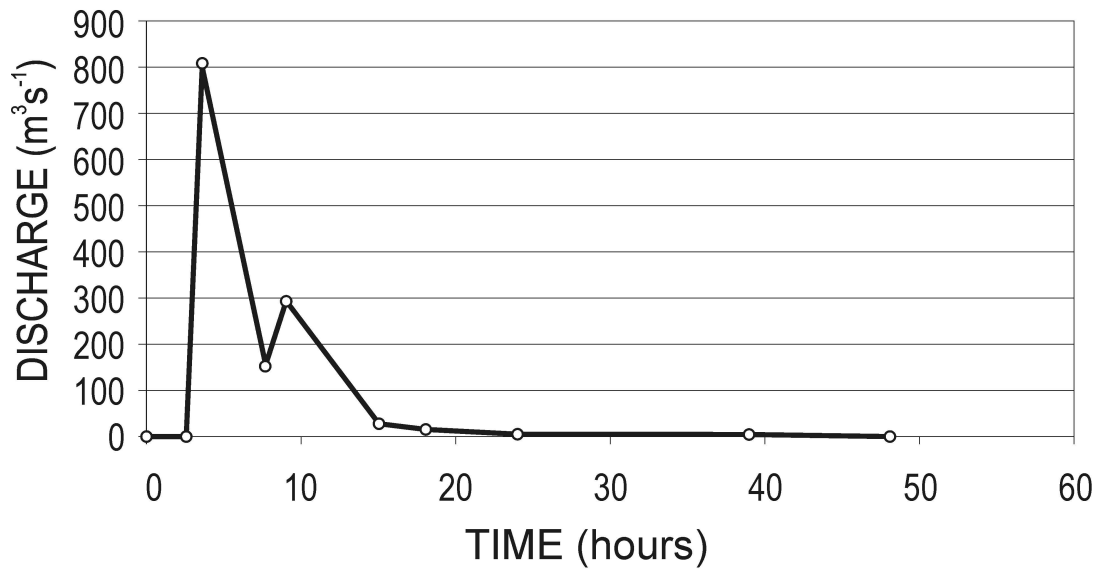

